\title{
HUBUNGAN RASA MEMILIKI DAN KOMITMEN DENGAN MOTIVASI BERPRESTASI PEMAIN FUTSAL FAKULTAS DI UNIVERSITAS ISLAM SULTAN AGUNG SEMARANG
}

\author{
Imam Guswanto dan Inhastuti Sugiasih \\ Fakultas Psikologi Universitas Islam Sultan Agung Semarang \\ Email: inhastuti@unissula.ac.id
}

\begin{abstract}
Abstrak
Penelitian ini bertujuan untuk mengetahui hubungan antara rasa memiliki dan komitmen dengan motivasi berprestasi pemain futsal fakultas di Universitas Islam Sultan Agung (Unissula) Semarang. Penelitian ini menggunakan metode penelitian kuantitatif yang dilakukan pada 99 orang pemain futsal dari tiap fakultas. Penelitian ini menggunakan 3 skala pengukuran, yaitu Skala Motivasi Berprestasi, SOBI-P, dan Skala Komitmen. Skala Motivasi Berprestasi berjumlah 21 aitem dengan rentang daya beda 0,254-0,527 dan koefisien reliabilitas sebesar 0,771. SOBI-P berjumlah 17 aitem dengan rentang daya beda 0,569-0,732 dan koefisien reliabilitas sebesar 0,938. Skala Komitmen berjumlah 20 aitem dengan rentang daya beda 0,323-0,504 dan koefisien reliabilitas sebesar 0,831 . Teknik analisis data yang digunakan yaitu analisis regresi dua prediktor dan korelasi parsial. Hasil uji hipotesis pertama menunjukkan ada hubungan yang sangat signifikan antara rasa memiliki dan komitmen dengan motivasi berprestasi, dimana korelasi $R=0,757$ dan Fhitung=61,948 dengan taraf signifikansi sebesar $0,000(p<0,01)$. Hasil uji hipotesis kedua menunjukkan ada hubungan positif yang signifikan antara rasa memiliki dengan motivasi berprestasi, dimana korelasi ryx1-x2=0,252 dengan taraf siginifikansi $p=0,012(p<$ $0,05)$. Hasil uji hipotesis ketiga menunjukkan ada hubungan positif yang sangat signifikan antara komitmen dengan motivasi berprestasi, dimana korelasi ryx1-x2 =0,630 dengan taraf signifikansi $p=0,000(p<0,01)$.
\end{abstract}

Kata kunci : Motivasi Berprestasi, Rasa Memiliki, Komitmen

\section{THE RELATIONSHIP BETWEEN SENSE OF BELONGING AND COMMITMENT WITH ACHIEVEMENT MOTIVATION ON FACULTY FUTSAL PLAYERS AT SULTAN AGUNG}

\begin{abstract}
This research aims to determine the correlation between the sense of belonging and commitment with achievement motivation on faculty futsal team players at Sultan Agung Islamic University (Unissula) Semarang. This research used quantitative research methods conducted on 99 futsal players from each faculty. This study used three measurement scales, The Achievement Motivation Scale, SOBI-P, and The Commitment Scale. The Achievement Motivation Scale consisted of 21 items with the coefficient correlation score starts from 0,254-0,527 and reliability coefficient equal to 0,771 . SOBI-P consisted of 17 items with the coefficient correlation score starts from 0,569-0,732 and reliability coefficient equal 0.938. Commitment scale consisted of 20 items with the coefficient correlation score starts from 0,323-0,504 and reliability coefficient equal to 0,831. The data analysis technique used are two predictors regression analysis and partial correlation. The results of the first hypothesis testing shows that there is a very significant relationship between sense of belonging and commitment with achievement motivation with correlation $R=0,757$ and $F_{\text {count }}=61,948$ with significance level equal to 0,000 ( $p$ $<0,01)$. The result of the second hypothesis testing shows that there is a significant positive correlation between sense of belonging and achievement motivation, where the correlation $r_{y \times 1-\times 2}=0,252$ and significance level $p=$ $0,012(p<0,05)$. The result of the third hypothesis testing shows that there is a very significant positive relationship between commitment and achievement motivation, where the correlation $r_{y \times 1-\times 2}=0,630$ and significance level $p=0,000(p<0,01)$.
\end{abstract}

Keywords: Achievement Motivation, Sense of Belonging, Commitment 
Hubungan Rasa Memiliki dan Komitmen Dengan Motivasi Berprestasi Pemain Futsal Fakultas di Universitas Islam Sultan Agung Semarang Proyeksi, Vol. 13 (2) 2018, 144-155

\section{Pendahuluan}

Futsal merupakan salah satu cabang olahraga yang cukup digemari saat ini. Hal ini terlihat dari semakin banyak kejuaraan futsal yang diselenggarakan di tiap kota di Indonesia. Futsal merupakan salah satu cabang olahraga yang memiliki kemiripan dengan sepakbola namun memiliki ukuran lapangan, bola, dan aturan yang berbeda, yang dimainkan lima lawan lima (Lhaksana, 2011). Dewi dan Prihatanta (2015) menambahkan bahwa tim yang membuat gol lebih banyak daripada kemasukan bola di gawang sendiri dinyatakan sebagai pemenang.

Futsal sendiri diperkenalkan oleh pelatih Tim Nasional Argentina, Juan Ceriani, pada Piala Dunia tahun 1930, yang saat itu diselenggarakan di Montevideo, Uruguay. Ceriani yang saat itu melatih timnas Argentina terkendala masalah cuaca saat ingin mengadakan latihan di lapangan karena hujan. Pola latihan Ceriani yang dimainkan dengan lima pemain melawan lima pemain di dalam ruangan ini mengundang minat para penonton untuk menyaksikan latihan timnas Argentina tersebut. Mulai saat itu pola latihan tersebut berkembang menjadi sebuah permainan yang digemari banyak orang (Halim, 2012). Pertandingan merupakan ajang untuk mempromosikan suatu olahraga dan juga ajang yang dapat melibatkan olahragawan atau tim olahraga bersaing dalam mencapai suatu prestasi. Pertandingan sebagai ajang pembuktian olahragawan atas hasil latihan yang telah dilaksanakan sebelum pertandingan. Setyani dan Khamidi (2013) menjelaskan bahwa pertandingan merupakan suatu sistem dalam event olahraga yang berbentuk kegiatan dengan menggunakan peraturan yang berlaku serta dikenal istilah menang, kalah, dan seri untuk menentukan hasil. Setyani dan Khamidi (2013) menambahkan bahwa pertandingan juga berguna dalam meningkatkan kemampuan individu yang terlibat melalui kegiatan fisik dan saling mengalahkan untuk memperoleh prestasi. Futsal merupakan olahraga yang membutuhkan teknik, taktik dan kondisi fisik baik agar suatu tim mampu mengakhiri pertandingan dengan kemenangan. Mc. Clelland (Rosmita \& Nainggolan, 2015) menjelaskan bahwa individu yang memiliki motivasi berprestasi akan terdorong untuk meraih pencapaian atau prestasi. Effendi (2016) juga menyebutkan bahwa motivasi berprestasi dapat mendorong atlet untuk menunjukkan kemampuan terbaiknya dan mampu mengarahkan atlet dalam memahami metode latihan yang diberikan pelatih dengan cepat. Atlet yang memiliki motivasi berprestasi tinggi mampu memahami pemberian materi yang diberi pelatih dengan tingkat kesulitan yang tinggi dibanding atlet yang memiliki motivasi berprestasi rendah (Effendi R. , 2016). Motivasi berprestasi sangat penting dimiliki oleh tiap pemain futsal apabila memiliki keinginan untuk berprestasi, karena tidak dapat dipungkiri bahwa tim futsal dibentuk dengan harapan mampu berprestasi dan menjuarai berbagai turnamen.

Motivasi berprestasi dapat menggerakkan pemain untuk bangkit dari permasalahan saat mengalami kekalahan dalam bertanding. Motivasi berprestasi juga mampu mendorong pemain untuk mempersiapkan diri dengan gigih saat latihan agar mendapatkan hasil yang memuaskan saat bertanding, kemudian mengarahkan tim untuk berprestasi dengan dorongan tersebut. Gill (Gould \& Weinberg, 2007) menjelaskan bahwa motivasi berprestasi adalah suatu pandangan individu untuk berorientasi pada pencapaian, kesuksesan, bertahan ketika gagal, dan memperoleh penghargaan saat meraih prestasi.

Hasil penelitian yang dilakukan oleh Goodanew dan Graady (1993) juga dapat diterapkan pada pemain futsal. Pemain futsal dengan rasa memiliki terhadap tim juga akan menganggap tim menyenangkan, bermanfaat, dan terdorong untuk terlibat dan berusaha dalam mencapai prestasi. Hasibuan (Santi, 2012) juga menambahkan bahwa rasa memiliki mampu menjadi kekuatan penggerak 
individu agar individu merasa diterima dalam suatu kelompok, sehingga individu tersebut mampu menggunakan seluruh kemampuan yang dimiliki dalam menyelesaikan suatu tanggung jawab dalam kelompoknya. Pemain futsal dengan rasa memiliki akan merasa diterima, senang berada dalam tim, kemudian terdorong untuk menggunakan seluruh kemampuan saat menyelesaikan tanggung jawab dalam tim dan meraih prestasi.

Faktor yang mempengaruhi motivasi berprestasi pemain selain rasa memiliki adalah komitmen pemain terhadap tim. Jenny (Mulyana, 2013) berpendapat bahwa komitmen merupakan suatu hal yang dapat membuat individu membulatkan hati dan tekad untuk mencapai tujuannya, walaupun individu tersebut belum mengetahui hasil akhir dari usahanya. Jatmiko, Swasto \& Eko (2015) dalam penelitianya pada karyawan di salah satu pabrik mengungkapkan bahwa komitmen karyawan terhadap organisasi merupakan keyakinan dan kepercayaan yang dimiliki karyawan terhadap nilai-nilai dan tujuan organisasi. Karyawan dengan komitmen memiliki keinginan kuat untuk menjadi bagian dari organisasi dan rela berusaha secara sungguh-sungguh agar tujuan organisasi kerja terealisasikan (Jatmiko, Swasto, \& Eko N, 2015).

\section{Tinjauan Literatur \\ Pengertian Motivasi Berprestasi}

Kata motivasi berasal dari bahasa latin yaitu movere, yang artinya kekuatan penggerak atau dorongan. Stanford (Mangkunegara, 2005) mengemukakan bahwa motivasi merupakan kondisi yang mampu menggerakkan manusia untuk meraih tujuan tertentu. Motivasi merupakan suatu dorongan atau kekuatan yang mampu menggerakkan seseorang untuk bertindak dengan cara tertentu untuk mencapai tujuan. Irwanto (1997) juga menjelaskan bahwa motivasi merupakan penggerak individu dalam bertindak dan bertingkah laku.

Motivasi ini mampu mendorong tiap individu mencapai tujuan diri sendiri maupun tujuan bersama kelompok atau organisasi. Seperti yang dikemukakan oleh Mangkunegara (2005) bahwa motivasi merupakan kekuatan yang mampu menggerakkan individu secara terarah dan tertuju pada pencapaian tujuan organisasi atau bersama. Motivasi dapat diartikan sebagai kekuatan pendorong yang mampu menggerakkan individu dalam bertindak dan bertingkah laku dengan cara tertentu untuk meraih tujuan pribadi atau kelompok.

Banyak hal yang mampu memotivasi individu untuk mencapai tujuan, misalnya saat individu berusaha dalam memenuhi kebutuhannya. Hal tersebut sejalan dengan yang dikemukakan oleh Mc. Clelland (Munandar, 2008) bahwa manusia dapat bergairah dalam bekerja ketika dia ingin memenuhi kebutuhannya. Mc. Clelland (Hasibuan, 2007) pun mengelompokkan tiga kebutuhan yang mampu memotivasi individu untuk bekerja yaitu kebutuhan berprestasi (need of achievement), kebutuhan berafiliasi (need of affiliation), dan kebutuhan akan kekuasaan (need of achievement). Ketiga kebutuhan tersebut terbukti dapat menjadi unsur yang sangat penting dalam menentukan prestasi individu dalam bekerja (Herlambang, 2014).

Mc. Clelland (Munandar, 2008) lebih banyak melakukan penelitian tentang kebutuhan berprestasi (need of achievement). Mc. Clelland menemuk bahwa terdapat perbedaan antara orang yang memiliki dorongan berprestasi tinggi dengan orang yang memiliki dorongan berprestasi rendah. Mereka lebih memiliki keinginan yang kuat dan mampu melakukan berbagai hal dengan baik. Dorongan tersebut sering disebut motivasi berprestasi (achievement motivation). Individu dengan 
Hubungan Rasa Memiliki dan Komitmen Dengan Motivasi Berprestasi Pemain Futsal Fakultas di Universitas Islam Sultan Agung Semarang Proyeksi, Vol. 13 (2) 2018, 144-155

motivasi berprestasi tinggi lebih menyukai beban tugas dimana mereka memiliki tanggung jawab pribadi untuk menyelesaikan tugas yang diberikan kepadanya.

Banyak faktor yang dapat mempengaruhi motivasi berprestasi individu. Suryabrata (2002) menyebutkan bahwa terdapat beberapa faktor yang mampu mempengaruhi motivasi berprestasi antara lain:

a. Faktor eksternal, yaitu faktor yang berada di luar diri individu. Faktor eksternal terdiri dari faktor sosial dan non-sosial.

1) Faktor sosial, merupakan faktor yang berkaitan dengan hubungan terhadap manusia baik secara langsung ataupun tidak langsung.

2) Faktor non-sosial, merupakan faktor yang berada di luar lingkungan sosial seperti cuaca, waktu, suhu, tempat, dan lain-lain.

b. Faktor internal, yaitu faktor yang berasal dari dalam diri individu. Faktor internal terdiri dari faktor fisiologis dan psikologis.

1) Faktor fisiologis, yaitu faktor yang terkait dengan keadaan jasmani individu, seperti keadaan, individu apakah sedang sehat atau sakit.

2) Faktor psikologis, yaitu faktor yang terkait dengan kebutuhan psikologis individu dan umumnya bersifat individu, seperti pengalaman, cita-cita, ingatan, perhatian, motif-motif dan lain-lain yang mendorong individu untuk belajar.

Asnawi (2002) menyebutkan bahwa terdapat empat aspek motivasi berprestasi individu, yaitu:

a. Mengambil tanggung jawab atas pekerjaan,

Individu dengan motivasi berprestasi tinggi akan merasa bertanggung jawab untuk menyelesaikan tugas yang telah dikerjakannya. Individu tersebut tidak akan meninggalkan tugasnya sebelum tugas tersebut selesai dikerjakan.

b. Melihat umpan balik (feed back) atas yang telah dikerjakan,

Pemberian umpan balik atas usaha atau hasil kerja keras yang telah dilakukan akan sangat disukai oleh individu dengan motivasi berprestasi tinggi. Individu tersebut juga akan berusaha untuk membenahi atau memperbaiki hasil kerja di masa mendatang.

c. Mempertimbangkan resiko,

Individu yang memiliki motivasi berprestasi tinggi cenderung mempertimbangkan suatu resiko yang akan dihadapi sebelum memulai suatu pekerjaan. Individu tersebut akan memilih tugas dengan beban sedang. Individu tersebut juga akan memilih tugas yang cukup menantang dan memiliki kemungkinan untuk berhasil sehingga individu tersebut mampu menyelesaikan tugas tersebut dengan baik.

d. Kreatif-inovatif

Individu yang memiliki motivasi berprestasi tinggi cenderung akan menyelesaikan suatu pekerjaan atau permasalahan dengan berbagai cara yang berbeda-beda. Cara-cara yang digunakan dalam menyelesaikan suatu tugas dengan cara kreatif, inovatif, efektif dan seefisien mungkin.

\section{Pengertian Rasa Memiliki}

Hasibuan (2007) mengungkapkan bahwa rasa memiliki merupakan salah satu bentuk kebutuhan berafiliasi yang mampu menggerakkan individu merasa diterima dalam suatu kelompok, sehingga mampu menggunakan seluruh kemampuan untuk menyelesaikan suatu tugas dan tanggung jawab dalam kelompok tersebut. Rasa memiliki merupakan suatu keterlibatan antara perasaan, keyakinan, 
dan harapan bahwa seseorang merasa cocok dalam suatu kelompok. Individu dengan rasa memilki akan merasa diterima oleh kelompok, serta bersedia berkorban demi kelompok (McMillan \& Chavis, 1986).

Hagerty, dkk (1992) menjelaskan bahwa rasa memiliki merupakan pengalaman keterlibatan individu terhadap suatu sistem atau lingkungan yang membuat individu tersebut merasa menjadi bagian dari sistem atau lingkungan tersebut. Muhaeminah (2015) menjelaskan bahwa rasa memiliki adalah terlibatnya atau keikutsertaan seseorang dalam sebuah kelompok tertentu dan merasa memiliki andil atau peran dalam kelompok tersebut. Goodenaw (Muhaeminah, 2015) mengungkapkan bahwa rasa memiliki merupakan perasaan diterima, dihargai, merasa terlibat, menjadi bagian penting dan berharga dalam kelompok.

Anant (Muhaeminah, 2015) menyatakan bahwa rasa memiliki mempunyai dua aspek utama, yaitu:

a. Memiliki pengalaman akan penghargaan dari sebuah keterlibatan

b. Merasa kecocokan sebagai bagian atau anggota dari sebuah kelompok.

Hagerty (Muhaeminah, 2015) menyusun kembali aspek penyusun rasa memiliki yang telah diungkapkan oleh Anant dengan menghadirkan antecedent yang terdiri dari tiga penyusun utama. Hagerty (Muhaeminah, 2015) kemudian menyusun sebuah instrumen yang disebut SOBI (Sense of Belonging Instrument), yang terdiri dari dua aspek dan tiga aspek dari dihadirkannya antecedent yang mendasari pembentukan SOBI:

a. Aspek rasa memiliki yaitu

1) Valued Involvement, merupakan pengalaman individu yang memiliki perasaan dihargai, dibutuhkan, diperlukan, dan merasa diterima.

2) Fit, merupakan anggapan individu bahwa karakteristik yang dimiliki telah sesuai dengan lingkungan dan sistem tempat dia berada.

b. Antecedent atau pemicu rasa memiliki merupakan seluruh hal atau peristiwa yang terjadi sebelum timbulnya rasa memiliki. Antecedent dari rasa memiliki antara lain:

1) Energy for involvement (kekuatan untuk merasakan keterlibatan)

2) Potential and desires for meaningful involvement (potensi dan keinginan untuk memaknai keterlibatan)

3) Potential for shared or complementary characteristics (potensi untuk berbagi dan melengkapi karakter).

\section{Pengertian Komitmen}

Robbins \& Judge (2008) menjelaskan bahwa komitmen merupakan keadaan dimana seorang individu merasa terikat dengan organisasi dan tujuan-tujuan organisasi sehingga membuat individu tersebut berkeinginan untuk mempertahankan keanggotaannya dalam organisasi. Komitmen sering dikaitkan dengan suatu organisasi, oleh karena itu banyak sumber yang menjelaskan dan mendefinisikan komitmen organisasi dibanding menjelaskan komitmen saja. Aamodt (2010) menjelaskan bahwa komitmen individu terhadap organisasi berasal dari keinginan individu mengidentifikasi tujuan organisasi dan tugasnya sebagai bagian dari organisasi. Individu yang memiliki komitmen terhadap organisasi akan menunjukkan kinerja yang baik, selalu terlibat dalam mencapai tujuan organisasi, dan setia terhadap organisasi. 
Hubungan Rasa Memiliki dan Komitmen Dengan Motivasi Berprestasi Pemain Futsal Fakultas di Universitas Islam Sultan Agung Semarang Proyeksi, Vol. 13 (2) 2018, 144-155

Colquitt, LePine \& Wesson (2015) menjelaskan bahwa komitmen didefinisikan sebagai keinginan seorang individu untuk tetap menjadi bagian dari kelompok atau organisasi. Komitmen dapat berpengaruh pada individu dalam suatu organisasi yang mampu mendorong individu untuk bertahan dengan segala kondisi yang ada di organisasi atau malah memilih mundur sebagai anggota organisasi. Newstorm (Wibowo, 2015) menjelaskan bahwa komitmen merupakan tingkatan dimana anggota kelompok atau organisasi mampu mengidentifikasi dan berpartisipasi secara aktif di dalam kelompok atau organisasi. Anggota yang mampu mengidentifikasi organisasinya akan mampu membaur bersama anggota yang lain dengan baik, sesuai etika dan harapan organisasi. Meyer dan Allen (Sutrisno, 2013) menemukan 3 komponen pembentuk komitmen organisasi, yaitu:

a. Komitmen Afektif

Komponen pembentuk komitmen individu dalam suatu organisasi yang merupakan kelekatan atau keterikatan secara psikologis antara individu dengan anggota lain yang ada di organisasi. Bentuk komitmen ini dapat terjadi dalam kelompok atau organisasi karena adanya rasa nyaman, aman dan manfaat lain yang dirasakan oleh individu. Hal demikian dapat berkembang karena individu tidak merasakan seperti itu di tempat atau organisasi lain. Semakin individu merasa nyaman dan merasa banyak memperoleh manfaat yang dirasakan sebagai anggota, maka semakin tinggi komitmen individu terhadap organisasinya tersebut.

b. Komitmen keberlanjutan

Komponen ini dapat diartikan sebagai keterikatan individu sebagai anggota dalam suatu organisasi karena konsekuensi yang didapatkan setelah bergabung. Individu akan memperhitungkan manfaat yang diperoleh dan seberapa besar yang telah dia berikan kepada organsasi. Komponen ini menjelaskan bahwa komitmen individu muncul dan menyebabkan individu tetap bertahan pada organisasinya. Hal demikian disebabkan karena individu tersebut membutuhkan posisi atau menjadi bagian dalam organisasi tersebut, selain itu individu tersebut memperoleh keuntungan lain, dan tidak menemukan organisasi lain untuk mengembangkan diri.

c. Komponen normatif

Komponen ini dijelaskan sebagai suatu keterikatan individu sebagai anggota dalam suatu organisasi karena individu tersebut merasa memiliki kewajiban secara moral untuk menjaga hubungan baik dengan organisasi. Komponen ini juga menjelaskan bahwa individu yang memiliki komitmen terdorong untuk tetap berada dalam organisasi dan memberikan pengorbanan dalam wujud apapun baik materi maupun non-materi.

Kondisi ini menunjukkan bagaimana individu tetap bertahan dalam suatu organisasi dikarenakan merasa harus memenuhi kewajibannya terhadap organisasi. Kondisi tersebut berasal dari nilai-nilai dalam diri individu dan kesadaran bahwa menjadi sebuah keharusan untuk berkomitmen terhadap organisasi.

\section{Metode Penelitian}

Variabel merupakan suatu objek yang memiliki bermacam-macam variasi dan menjadi yang diteliti dalam suatu penelitian. Penelitian ini melihat hubungan antara tiga variabel psikis. Variabel psikis adalah variabel yang terkait dengan keadaan psikologis manusia, mencakup aspek kognitif, afektif, dan psikomotor (Periantalo, 2016). Penilitian ini memiliki dua macam variabel yaitu variabel bebas dan variabel tergantung. Variabel tergantung merupakan variabel yang muncul karena dipengaruhi oleh variabel lain, yang dimaksud variabel lain disini ialah variabel bebas. 
1. Variabel Tergantung $(\mathrm{Y}) \quad$ : Motivasi berprestasi

2. Variabel Bebas:

a. Variabel bebs 1 (X1) : Rasa memiliki

b. Variabel bebas $2(\mathrm{X} 2) \quad$ : Komitmen

Metode pengumpulan data yang digunakan dalam penelitian ini yaitu menggunakan skala likert. Skala likert digunakan dalam suatu penelitian untuk mengukur sikap, pendapat, atau persepsi seseorang mengenai fenomena sosial (Sugiyono, 2014). Skala likert disusun dalam bentuk pernyataan untuk mengungkapkan sikap atau respon subjek penelitian, kemudian diberi skor dan diinterpretasikan (Azwar, 2012). Teknik pengambilan sampel dalam penelitian ini menggunakan teknik cluster random sampling. Teknik tersebut digunakan untuk memilih subjek berdasarkan daerah atau wilayah tertentu. Teknik ini membagi subjek berdasarkan wilayah atau daerah. Teknik tersebut bisa melibatkan seluruh wilayah atau daerah tempat populasi yang akan diteliti, namun juga bisa hanya melibatkan beberapa daerah atau wilayah saja dalam suatu populasi (Periantalo, 2016).

Teknik analisis data digunakan untuk melihat hipotesis yang diajukan dapat diterima atau ditolak. Teknik analisis dalam penelitian ini menggunakan dua teknik analisis data, yaitu teknik analisis regresi dua prediktor dan teknik analisis korelasi parsial. Kedua teknik analisa data tersebut dilakukan dengan bantuan SPSS (Statistical Product and Service Solution) versi 17.0.

Teknik analisis regresi dua prediktor digunakan untuk menguji hipotesis pertama dalam penelitian ini. Teknik analisis regresi dua prediktor digunakan untuk mengukur hubungan antara variabel bebas dan tergantung dimana terdapat variabel bebas berjumlah dua atau lebih (Sugiyono, 2014). Analisis regresi dua prediktor dapat menunjukkan seberapa berpengaruh variabel bebas terhadap variabel tergantung melalui sumbangan efektif (Siregar, 2015).

\section{Uji Normalitas}

Uji normalitas dilakukan untuk mengetahui normal atau tidaknya distribusi data dari variabel penelitian. Penelitian ini menggunakan teknik One-Sample-Kolmogorov-Smirnov untuk uji normalitas. Ketentuan untuk menentukan sebaran distribusi normal yaitu $p>0,05$, sedangkan ketentuan untuk menentukan sebaran distribusi tidak normal jika $p<0,05$. Hasil uji normalitas dalam penelitian ini dapat dilihat pada tabel berikut:

Tabel 10. Hasil analisis uji normalitas

\begin{tabular}{lcccccc}
\hline \multicolumn{1}{c}{ Variabel } & Mean & $\begin{array}{c}\text { Std } \\
\text { Deviasi }\end{array}$ & KS-Z & Sig & P & Keterangan \\
\hline $\begin{array}{l}\text { Motivasi } \\
\text { Berprestasi }\end{array}$ & 62,474 & 7,756 & 0,742 & 0,641 & $>0,05$ & Normal \\
$\begin{array}{l}\text { Rasa } \\
\text { Memiliki }\end{array}$ & 49,565 & 9,132 & 1,584 & 0,013 & $<0,05$ & Tidak Normal \\
Komitmen & 61,646 & 8,618 & 0,684 & 0,737 & $>0,05$ & Normal \\
\hline $\begin{array}{l}\text { Hasil uji } \\
\text { normalitas }\end{array}$ & yang telah dilakukan pada sebaran data motivasi berprestasi \\
menunjukkan nilai KS-Z sebesar 0,742 dengan taraf signifikansi & sebesar 0,641 (p>0,05). Hal \\
tersebut menandakan bahwa sebaran data motivasi berprestasi memiliki distribusi data yang \\
normal.
\end{tabular}


Hubungan Rasa Memiliki dan Komitmen Dengan Motivasi Berprestasi Pemain Futsal Fakultas di Universitas Islam Sultan Agung Semarang Proyeksi, Vol. 13 (2) 2018, 144-155

Hasil uji normalitas yang telah dilakukan pada sebaran data rasa memiliki menunjukkan nilai KS-Z sebesar 1,584 dengan taraf signifikansi sebesar 0,013 $(p<0.05)$. Hal tersebut menandakan bahwa sebaran data rasa memiliki tidak normal.

Hasil uji normalitas yang telah dilakukan pada sebaran data komitmen menunjukkan nilai KS$Z$ sebesar 0,684 dengan taraf signifikansi sebesar $0,737(p>0,05)$. Hal tersebut menandakan bahwa sebaran data komitmen memiliki distribusi data yang normal.

\section{Uji Linearitas}

Uji linearitas merupakan tahapan yang dilakukan setelah melakukan uji asumsi. Uji linearitas dilakukan untuk mengetahui hubungan antar variabel apakah memiliki hubungan yang signifikan atau tidak. Uji linearitas yang digunakan dalam penelitian ini yaitu Uji F.

Hasil uji linearitas antara variabel motivasi berprestasi dengan variabel rasa memiliki diperoleh $F_{\text {linier }}$ sebesar 36,894 dengan taraf signifikansi $p=0,000(p<0,01)$. Hal tersebut menunjukkan adanya hubungan yang linear antara variabel motivasi berprestasi dengan rasa memiliki.

Hasil uji linearitas antara variabel motivasi berprestasi dengan variabel komitmen diperoleh

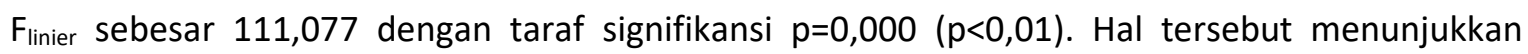
adanya hubungan yang linear antara variabel motivasi berprestasi dengan komitmen.

\section{Uji Multikolinearitas}

Uji multikolinearitas dilakukan dengan tujuan untuk mengetahui apakah ada hubungan antar variabel bebas pada model regresi. Uji multikolinearitas dalam penelitian ini menggunakan Teknik VIF (Variance Inflanting Factory) dengan nilai VIF $<10$. Jika terdapat multikolinearitas antar variabel bebas atau terdapat hubungan antar variabel bebas, maka tidak dapat dilakukan analisis regresi ganda.

Hasil uji multikolinearitas pada variabel rasa memiliki diperoleh nilai VIF sebesar 1,451 (VIF<10) dan hasil uji multikolinearitas pada variabel komitmen diperoleh nilai VIF sebesar 1,451 (VIF<10). Berdasarkan hasil uji multikolinearitas menunjukkan bahwa tidak terjadi multikolinearitas antar variabel bebas sehingga dapat dilaksanakan analisis regeresi ganda

\section{Uji Hipotesis}

Hasil perhitungan menggunakan teknik analisis regresi dua prediktor diperoleh korelasi R sebesar 0,751 dan $F_{h i t u n g}$ sebesar 61,948 dengan taraf signifikansi sebesar $0,000(p<0,01)$. Hasil tersebut menunjukkan bahwa hipotesis pertama diterima, dimana terdapat hubungan antara rasa memiliki dan komitmen dengan motivasi berprestasi. Berdasarkan hasil perhitungan juga diperoleh $\mathrm{R}$ Square sebesar 0,563. Hal tersebut menunjukkan bahwa sumbangan efektif antara rasa memiliki dan komitmen memberikan kontribusi sebesar $56,3 \%$ terhadap motivasi berprestasi.

Uji hipotesis kedua dilakukan untuk menguji apakah ada hubungan positif antara rasa memiliki dengan motivasi berprestasi. Hasil perhitungan diperoleh nilai korelasi $r_{y \times 1-\times 2}=0,252$ dengan taraf siginifikansi $p=0,012(p<0,05)$. Hasil berikut menandakan bahwa hipotesis kedua diterima, yang berarti terdapat hubungan positif yang signifikan antara rasa memiliki dengan motivasi berprestasi. Semakin tinggi rasa memiliki individu, maka akan semakin tinggi juga tingkat motivasi berprestasi individu tersebut. Sebaliknya, jika semakin rendah rasa memiliki individu tersebut maka semakin rendah pula motivasi berprestasinya.

Uji hipotesis ketiga dilakukan untuk menguji apakah terdapat hubungan positif antara komitmen dengan motivasi berprestasi. Hasil perhitungan diperoleh nilai korelasi $r_{y \times 1-\times 2}=0,630$ dengan taraf 
siginifikansi $p=0,000(p<0,01)$. Hasil berikut menunjukkan bahwa hipotesis ketiga diterima, yang berarti terdapat hubungan positif yang sangat signifikan antara komitmen dengan motivasi berprestasi. Semakin tinggi komitmen yang dimiliki oleh individu, maka akan semakin tinggi juga motivasi berprestasi individu tersebut. Sebaliknya, jika semakin rendah tingkat komitmen yang dimiliki individu tersebut maka semakin rendah pula motivasi berprestasinya.

\section{Kesimpulan}

Berdasarkan penelitian yang telah dilaksanakan pada pemain tim futsal fakultas di Unissula dapat disimpulkan bahwa:

1. Ada hubungan antara rasa memiliki dan komitmen dengan motivasi berprestasi Pemain Futsal Fakultas di Universitas Islam Sultan Agung Semarang.

2. Ada hubungan postif yang signifikan antara rasa memiliki dengan motivasi berprestasi Pemain Futsal Fakultas di Universitas Islam Sultan Agung Semarang.

3. Ada hubungan positif yang sangat signifikan antara komitmen dengan motivasi berprestasi Pemain Futsal Fakultas di Universitas Islam Sultan Agung Semarang.

\section{Saran}

Berdasarkan hasil penelitian yang telah dilaksanakan, peneliti berusaha memberikan saran sebagai berikut:

1. Bagi Pelatih

a. Pelatih diharapkan mampu menjaga tingkat rasa memiliki pemain terhadap tim futsal fakultas untuk menunjang semangat pemain untuk berkontribusi dalam tim.

b. Pelatih diharapkan mampu menjaga komitmen pemain untuk terus berusaha semaksimal mungkin dan memberikan segala kemampuannya untuk memajukan tim futsal fakultas.

2. Bagi Universitas dan Fakultas

a. Universitas maupun Fakultas diharapkan mampu mendukung dalam pengembangan sumber daya Pemain di tiap Tim Futsal Fakultas agar para pemain termotivasi untuk berprestasi dalm menjuarai berbagai pertandingan.

\section{DAFTAR PUSTAKA}

Aamodt, M. G. (2010). Industrial/organizational psychology: An applied approach. Belmont, CA: Wadsworth Cengage Learning.

Asnawi. (2002). Teori motivasi. Jakarta: Studi Press.

Azwar. (2010). Metode penelitian. Yogyakarta: Pustaka Pelajar.

Azwar. (2012). Penyusunan skala psikologi. Yogyakarta: Pustaka Pelajar.

Colquitt, J. A., LePine, J. A., \& Wesson, M. J. (2015). Organizational behavior: Improving performance and commitment in the workplace. New York: McGraw-Hill Education.

Curtis, S., \& Wright, D. (2001). Retaining employees - The fast track to commitment. Management Research News , 24 (8/9), 59-64.

Degeng. (1997). Strategi pembelajaran, mengorganisasi isi dengan model elaborasi. Malang: IKIP Malang \& Biro Penerbitan Ikatan Profesi Teknologi Pendidikan.

Dewi, \& Prihatanta. (2015). Hubungan berat badan dan tinggi badan dengan kelincahan pemain futsal putri UNY. Medikora, 16 (2). 
Hubungan Rasa Memiliki dan Komitmen Dengan Motivasi Berprestasi Pemain Futsal Fakultas di Universitas Islam Sultan Agung Semarang Proyeksi, Vol. 13 (2) 2018, 144-155

Dirwan. (2014). Pengaruh kualitas pelayanan dan komitmen mahasiswa terhadap motivasi berprestasi mahasiswa perguruan tinggi swasta. Jurnal Cakrawala Pendidikan , 3 (3), 379-391.

Dwianasari, R., \& Mardiasmo. (2004). Pengaruh hubungan antara partisipasi anggaran dan struktur desentralisasi pada kinerja manajer agensi pemerintahan daerah: Peran komitmen organisasi sebagai variabel intervensi (Studi tentang Kotamdya dan Kabupaten di Provinsi Yogyakarta). Sosiosains , 17 (4), 655-674.

Effendi. (2016). Pengaruh metode latihan practice session, test session dan motivasi berprestasi terhadap keterampilan menendang dalam sepak bola. Jurnal Pendidikan Unsika , 4 (1), 91-106.

Fernald, L. D., \& Fernald, P. S. (2004). Introduction to psychology (5th Edition ed.). Delhi: A.I.T.B.S Publishers \& Distributors (Regd).

Ferreira, Cardoso, \& Abrantes. (2011). Motivation and relationship of the student with the school as factors involved in the perceived learning. Procedia: Social and Behavioral Sciences, 17071714.

Freeman, Anderman, \& Jensen. (2007). Sense of belonging in college freshmen at The Classroom and Campus Levels. The Journal of Experimental Education , 75 (3), 203-220.

Goodenow, \& Grady. (1993). The relationship of school belonging and friends' values to academic motivation among urban adolescent students. Journal of Experimental Education , 62 (1), 6071.

Gould, D., \& Weinberg, R. S. (2007). Foundations of sport and exercise psychology (4th edition). IL Champaign: Human Kinetics.

Gunarsa. (2008). Psikologi perkembangan anak dan remaja. Jakarta: BPK Gunung Mulia.

Guspa, A., \& Rahmi, T. (2014). Hubungan antara persepsi terhadap financial reward dengan komitmen kerja pada Atlet. Jurnal RAP UNP , 5 (1), 1-11.

Hagerty, \& Patusky. (1995). Developing a measure of sense of belonging. Nursing Research , 44 (1), 913.

Hagerty, B. M., Lynch-Sauer, J., Patusky, K. L., Bouwsema, M., \& Collier. (1992). Sense of belonging: A vital Mental health concept. Archives of Psychiatric Nursing , VI (3), 172-177.

Halim, S. (2012). 1 Hari pintar main futsal. Yogyakarta: MedPress Digital.

Hasibuan, M. S. (2007). Organisasi \& motivasi. Bandung: Bumi Aksara.

Heckhausen. (1967). The anatomy of achievement motivation. New York: Academic Press.

Herlambang, S. (2014). Perilaku organisasi: cara mudah mempelajari perilaku manusia dalam sebuah organisasi. Sleman: Gosyen Publishing.

Irwanto. (1997). Psikologi umum. Jakarta: Gramedia Pustaka Utama.

Jatmiko, E. D., Swasto, B., \& Eko N, G. (2015). Pengaruh motivasi kerja dan komitmen organisasional terhadap kinerja karyawan (Studi pada karyawan kompartemen pabrik II PT. Petrokimia Gresik). Jurnal Administrasi Bisnis (JAB) , XXI (1), 1-8.

Kreitner, \& Kinicki. (2010). Organizational behavior. New York: McGraw-Hill.

Kusumawati, \& Mylsidayu. (2015). Analisis anxiety atlet PORDA Kota Bekasi. Motion , 6 (1), 1-16.

Kusumawati, M. (2016). Pengaruh circuit training terhadap daya tahan atlet futsal SWAP Jakarta dalam Indonesia Futsal League (IFL) 2013. Jurnal Pendidikan Olahraga , 3 (1), 27-34.

Lhaksana, J. (2011). Taktik \& strategi futsal modern. Depok: Be Champion. 
Manggarani, \& Supraptiningsih. (2015). Hubungan antara peran kelompok teman sebaya dengan motivasi berprestasi pada Mahasiswa Fakultas Psikologi Universitas Islam Bandung angkatan 2011. Prosiding Penelitian Sivitas Akademika Unisba (Sosial dan Humaniora) (pp. 164-172). Bandung: Unisba.

Mangkunegara. (2005). Manajemen sumber daya manusia perusahaan. Bandung: PT. Remaja Rosdakarya.

McMillan, D. A., \& Chavis, D. M. (1986). Sense of community: A definition and theory. Journal of Community Psychology , 14 (1), 6-23.

Muhaeminah. (2015). Game therapy untuk meningkatkan sense of belonging anak panti asuhan. Jurnal IImiah Psikologi Terapan , 3 (1), 32-53.

Mulyana. (2013). Hubungan konsep diri, komitmen, dan motivasi berprestasi dengan prestasi renang gaya bebas. Jurnal Cakrawala Pendidikan , 3 (3), 488-498.

Mulyasa. (2011). Praktik penelitian tindakan kelas. Bandung: Remaja Rosykarya.

Munandar, A. S. (2008). Psikologi industri dan organisasi. Jakarta: UI-Press.

Murwaningsari, E. (2008). The role of organizational commitment and procedural justice in moderating the relationship between budgetary participation and managerial performance. Gadjah Mada International Journal of Business, 10 (2), 185-210.

Periantalo, J. (2016). Penelitian kuantitatif untuk psikologi. Yogyakarta: Pustaka Pelajar.

Putri. (2014). Hubungan dukungan sosial orang tua, pelatih, dan teman sebaya dengan motivasi berprestasi akademik dan motivasi berprestasi olahraga (basket) pada Mahasiswa Atlet Basket Universitas Surabaya.

Radar Banjarmasin. (2016). Pemain 'nakal' dicoret. Banjarmasin: PT. Duta Prokal Multimedia.

Robins, S. P., \& Judge, T. A. (2008). Perilaku organisasi. Jakarta: Salemba Empat.

Rosmita, \& Nainggolan, K. (2015). Pengaruh kepemimpinan, iklim organisasi dan motivasi berprestasi terhadap kinerja karyawan PT. Bintang Mandiri Finance Jawa Barat. Ecodemica. , 3 (2), 516 528.

Santi, T. (2012). Menumbuhkan rasa cinta terhadap pekerjaan: Motivasi terhadap pegawai perpustakaan untuk meningkatkan kualitas pelayanan perpustakaan. Jurnal Iqra', 6 (1), 87-98.

Sardiman. (2007). Interaksi dan motivasi belajar-mengajar. Jakarta: Raja Grafindo Persada.

Schuler, H., Thornton, G. C., A, F., \& Hanson, R. M. (2004). AMI: Achievement motivation inventory (1st Edition ed.). Oxford: A Hogrefe Company.

Setyani, \& Khamidi. (2013). Evaluasi manajemen tim pertandingan dash karate club taman-Sidoarjo. Jurnal Prestasi Olahraga , 1 (1).

Siregar. (2015). Statistik parametrik untuk penelitian kuantitatif. Jakarta: Bumi Aksara.

Siswati. (2015). Hubungan Kompetensi pedagogik guru dan efikasi diri dengan motivasi berprestasi belajar siswa kelas IX SMP Islam Al-Ulum Terpadu Medan. Kultura , 16 (1), 4925-4935.

Sopiah. (2008). Perilaku organisasional. Yogyakarta: Andi.

Sugiyono. (2014). Metode penelitian kuantitatif dan R\&D. Bandung: Alfabeta.

Sulasmi. (2005). Hubungan komitmen organisasi dengan motivasi berprestasi pada Pegawai Administrasi Fakultas Hukum Universitas Islam Indonesia. Yogyakarta: Eprints UAD.

Surahman. (2008). Hubungan antara persepsi terhadap gaji dan komitmen organisasi dengan motivasi berprestasi. Surakarta: Eprints UMS.

Suryabrata. (2002). Psikologi pendidikan. Jakarta: Rajawali. 
Hubungan Rasa Memiliki dan Komitmen Dengan Motivasi Berprestasi Pemain Futsal Fakultas di Universitas Islam Sultan Agung Semarang Proyeksi, Vol. 13 (2) 2018, 144-155

Sutrisno, E. (2013). Budaya organisasi (1st Edition ed.). Jakarta: Kencana.

Triatna, C. (2015). Perilaku organisasi dalam pendidikan. Bandung: PT. Remaja Rosdakarya Offset.

Wattimena. (2015). Hubungan motivasi berprestasi dan kecemasan terhadap prestasi panahan ronde recurve pada Atlet Panahan di Indonesia. Motion , 6 (1), 109-122.

Wibowo. (2015). Perilaku dalam organisasi (2 ed.). Jakarta: Rajawali Pers.

Yuwono. (2015). Handarbeni dan sense of belonging di Universitas Muhammadiyah Surakarta. Proceeding Seminar Nasional "Selamatkan Generasi Bangsa dengan Membentuk Karakter Berbasis Kearifan Lokal" (pp. 208-215). Solo: Publikasi IImiah UMS. 